\title{
Polska i Rumunia. Wspólnie - obok - blisko. XVI Dni Polskie - Suczawa 4-6 września 2014 r.
} Tuż po raz $16 \mathrm{w}$ gościnnej Suczawie spotkali się naukowcy z Polski,
Rumunii i Mołdawii, aby przeprowadzić dyskurs o polsko-rumuńskich
stosunkach historycznych i kulturalnych, a także poruszyć zagadnienia
związane z tematyką bukowińską. Tegoroczne sympozjum przebiegało
pod hasłem: „Polska i Rumunia. Wspólnie - obok - blisko” i jak co roku
wpisane było w obchody Dni Polskich.

Obchody Dni Polskich zainaugurowane zostały otwarciem wystawy przygotowanej przez Ośrodek „Karta” i Instytut Kultury Rumuńskiej w Polsce, poświęconej życiu Polaków, przebywających na uchodźctwie u naszych południowych sąsiadów. Stąd też ekspozycja prezentowana była pod tytułem: „Życie codzienne Polaków na wychodźstwie w Rumunii (1939-1947)". Oglądający mogli zapoznać się ze zdjęciami wykonanymi w różnych miejscach i okolicznościach. Obraz wzbogacony był dodatkowo wspomnieniami Polaków, którzy lata 1939-1947 spędzili właśnie w Rumunii. Wśród osób otwierających wystawę byli: Gerwazy Longher (polski poseł w Rumunii), władze miasta Suczawy i województwa suczawskiego oraz senator Marek Konopka.

Po powitaniu i wymianie wzajemnych uprzejmości rozpoczęła się cześć naukowa XVI Dni Polskich. Pierwszą sekcję - „W kręgu historii” rozpoczął prof. dr Constantin Rezachevici (Bukareszt), który przedstawił zebranym, czym jest historyczna Bukowina. Wskazał na pochodzenie nazwy i na ewolucje terytorialne na przestrzeni wieków. Po nim głos zabrał prof. dr hab. Grzegorz Jawor (UMCS Lublin), prezentując następujące zagadnienie: „Etnika mieszkańców osad na prawie wołoskim i jej 
przemiany w Polsce na przełomie średniowiecza i czasów nowożytnych (XIV-XVI w.)". Reprezentująca Muzeum Bukowiny w Suczawie dr Monica Dejan referowała na temat monet polskich ze średniowiecznych skarbców, które odkryto na terenie Suczawy. O „nieznanej” bitwie polskomołdawskiej z roku 1506 r. mówiła dr Katarzyna Niemczyk (Uniwersytet Śląski w Katowicach). Natomiast przedstawicielka Mołdawskiej Akademii Nauk w Kiszyniowie - dr Lilia Zabolotnaia, zapoznała zebranych z „Tajemnicami posagu Marii Radziwiłł”. Kolejne dwa referaty w tej części obrad wygłosili: dr Constantin Antim Bobibescu (Bukareszt) - „Wstępne uwagi na temat tyranii $\mathrm{w}$ relacjach polsko-mołdawskich w okresie panowania rodu Mohyłów”, i dr Florian Pintescu - „Rumunia i bitwa pod Chocimiem, 10-11 listopada 1673. Analiza polityczna”.

Drugą grupę referatów w tej sekcji (po krótkiej przerwie) rozpoczął swoją prelekcją dr hab. Tomasz Ciesielski (Opole). Pozostał on w klimacie poprzednich wystąpień, referując o granicy polsko-mołdawskiej w XVIII w. Wskazał m.in. na jej przebieg, organizację i co naturalne, określił stosunki przygraniczne. Doktor Alina Felea (Kiszyniów) wygłosiła referat zatytułowany: „Testamenty z Bukowiny - testatorzy i sposób sporządzania (XVIII-pocz. XIX w.)". Akademię Rumuńską w Jassach reprezentował dr Veniamin Ciobanu. W trakcie sympozjum referował na temat powstania listopadowego i jego echa w szwedzkich raportach dyplomatycznych. Doktor Sorin Marcel Colesniuc (Muzeum w Mangali) w swoim wystąpieniu omówił działalność polskiej emigracji w Księstwach Rumuńskich w latach 1831-1848. Do XIX w. przeniosła słuchaczy także prof. dr Nicoleta Ciachir (Bukareszt), która omówiła interferencje kulturalne i rewolucyjne rumuńsko-polskie w II połowie XX w. W tej sekcji zaplanowany był jeszcze referat płk. Eugena Ichima, który jednakże nie przybył na sympozjum.

Trzecią część obrad sekcji „W kręgu kultury” zainicjował dr Ion Constantin, odczytując referat dr. Nicolae Mareşa (Bukareszt), który nie mógł przybyć do Suczawy. Tekst ten nosił tytuł „Constantin Stere i Józef Piłsudski - Rumun i Polak na zsyłce na Syberii”. Doktor Jan Wiśniewski (Toruń) - omówił polsko-rumuńską współpracę polityczno-wojskową w Rosji w trakcie I wojny światowej. Z kolei prof. dr hab. Waldemar Remzer (reprezentujący UMK w Toruniu) przybliżył postać Olgierda Górki, żołnierza, polityka i attaché wojskowego w Rumunii. Kolejnym reprezentantem Uniwersytetu Mikołaja Kopernika w Toruniu, który prezentował wyniki swoich badań, był dr hab. Aleksander Smoliński. Jego referat dotyczył stanowiska Rumunii wobec wojny polskosowieckiej, a swoje rozważania oparł na podstawie dokumentów polskich wypracowanych w $1920 \mathrm{r}$. Zupełnie innej tematyce poświęcony był referat 
dr. hab. Piotra Gołdyna (Kalisz), który omówił „Dziennik z podróży po Rumunii". Został on spisany przez studentów Uniwersytetu Poznańskiego, którzy w 1928 r. odbyli miesięczną podróż po Rumunii, a swoje spostrzeżenia pozostawili w formie dziennika. Kolejnym referentem miał być mgr Robert Mieczkowski z Łomży, który jednakże nie dotarł na sympozjum. Ostatnim referatem tego dnia było wystąpienie mgr. Tomasza Osucha (Kraków) na temat mniejszości narodowych w Rumunii w dwudziestoleciu międzywojennym.

Obrady w tej sekcji kontynuowane były także w drugim dniu sympozjum. Swoim zakresem objęły one okres od 1939 r. do współczesności. Referaty wygłoszone zostały w dwóch turach. Jako pierwszy wystąpił prof. dr hab. Andrzej Gąsiorowski (Gdańsk), z referatem zatytułowanym „Inicjatywy tworzenia konspiracji wojskowej prowadzone z terenu Rumunii 1939-1940". Doktor Marek Sioma (UMSC Lublin) zaprezentował wystąpienie pod tytułem, Biografie paralelne? - czyli o pobycie piłsudczyków generałów Sławoja Składkowskiego i Kordiana Zamorskiego w Rumunii w latach 1939-1940". W tym samym przedziale czasowym pozostała kolejna prelegentka - dr Maria Radziszewska (Olsztyn), która zaprezentowała działalność jednego z czołowych historyków wychowania - Lukasza Kurdybachy w Rumunii w latach 1939-1940. O internowaniu Józefa Becka w Rumunii referował dr Daniel Hernciuc (Rădăuţi). Z kolei dr Radu Florian Bruja (Suczawa) przeprowadził analizę kampanii niemieckiej przeciwko Polsce we wrześniu 1939 r. Jako ostatni w tej części obrad wystąpił dr Jarosław Durka (Częstochowa). Jego wystąpienie nosiło tytuł „Wybrane wątki polsko-rumuńskiej współpracy wywiadowczej po II wojnie światowej w dokumentach Instytutu Pamięci Narodowej w Warszawie".

Po krótkiej przerwie dokończono obrady w tej sekcji. Jako pierwszy głos zabrał dr Ion Constantin (Bukareszt), który mówił o roli, jaką odgrywała kultura w walce z totalitaryzmem w okresie Solidarności. Administrację lokalną w Rumunii omówił dr Adam Burakowski (Warszawa). „Zmiany nazwy języka państwowego Republiki Mołdawii w kontekście zarzutów o chęć zjednoczenia państwa z Rumunią" - tak brzmiał tytuł referatu, który zaprezentował dr Bartłomiej Zduniak (Warszawa). W tej sekcji zaplanowane były również wystąpienia dr. Aleksandra Gubrynowicza (Warszawa) - „Demograficzna katastrofa: perspektywa polska i rumuńska, koncepcje łagodzenia skutków przemian w kontekście analizy możliwości współpracy Polski i Rumunii w tym zakresie", oraz mgr. Krzysztofa Górskiego - „Kościoły większościowe w życiu politycznym Rumunii i w Polsce - analiza porównawcza". Ten ostatni tekst pod nieobecność prelegenta został odczytany przez dr. Burakowskiego. Poza programem 
odbyła się prezentacja pamiątek rodzinnych dokonana przez Aldonę Patraş-Rey.

Drugiego dnia obrad, pracowały również dwie pozostałe sekcje. W Domu Polskim w godzinach przedpołudniowych obradowała sekcja „W kręgu kultury”. Pierwszym prelegentem był dr hab. Krzysztof Walczak (Wrocław), który omówił edycje sprawozdań szkolnych z dawnych czerniowieckich gimnazjów. Po nim głos zabrała prof. dr Olimpia Mitric (Suczawa), ukazując zebranym dawne ślady polskie w dwóch biskupstwach: Romanu i Bakowa. O podręczniku do nauki języka polskiego przygotowanym dla Rumunów, a funkcjonującym w ostatnich latach przed wybuchem II wojny światowej mówiła mgr Zyta Monika Oksztul (Jassy). Doktor hab. Ewa Andrysiak (Łódź) zaprezentowała wystąpienie pod tytułem „Książka, biblioteka i prasa w Rumunii w świetle polskiej bibliografii lat 1990-2013”. Wykład dr. hab. Zdzisława Biegańskiego (Bydgoszcz) poświęcony był recepcji kina rumuńskiego w polskiej prasie filmowej ukazującej się w okresie PRL-u. „Zachwycające piekło, czyli recepcja filozofii Ciorana w młodej poezji polskiej" - tak zatytułowane było wystąpienie mgr. Olgierda Dziechciarza (Olkusz). Reprezentująca Uniwersytet Wrocławski mgr Joanna Małgorzata Banachowicz przedstawiła referat poświęcony Bukowinie widzianej oczyma Rose Ausländer. Z kolei mgr Łukasz Woiński (Kraków) referował na temat: „»Universum Transylvanie«. Relacje międzyetniczne W powieści Eginalda Schlattnera »Fortepian we mgle«". Jako ostatnia w tej sekcji wystąpiła mgr Agnieszka Majewska, która zaprezentowała swój autorski program edukacyjny realizowany $\mathrm{w}$ szkołach ponadgimnazjalnych na terenie Warszawy. Program ten poświęcony jest historii i kulturze Rumunii, a jego celem jest wykreowanie wizerunku tego kraju wolnego od postrzegania stereotypowego.

Kolejną sekcją, która już na stałe wpisała się sympozjum o stosunkach polsko-rumuńskich, była ta, poświęcona zagadnieniom związanym z Bukowiną - „W kręgu problematyki bukowińskiej”. O polszczyźnie Bukowińczyków mówił dr Jan Bujak z Krakowa. George Ostafi podjął temat „Heroizm, wzorzec, moda”. Doktorr hab. Krzysztof Nowak (Katowice) spojrzał na badania dr. Mariana Gotkiewicza, poświęcone Bukowinie z dzisiejszej perspektywy. Magister Adam Rossmanith w sposób niezwykle ciekawy omówił strukturę społeczno-demograficzną północnej Bukowiny, porównując ją z południową Bukowiną. „Kim jesteśmy? Uwagi o języku polskich mieszkańców Bulaju oraz ich »mazurskiej « autoidentyfikacji” to tytuł referatu wygłoszonego przez mgr Karinę Stempel-Gancarczyk (Warszawa). Ostatnim wystąpieniem był 
referat dr Magdaleny Pokrzyńskiej. Omówiła wzory kultury bukowińskiej w Muzeum Etnograficznym w Zielonej Górze.

Po zakończeniu obrad we wszystkich sekcjach miało miejsce podsumowanie połączone tradycyjnie $\mathrm{z}$ prezentacją publikacji poświęconych stosunkom polsko-rumuńskim i nie tylko. W dyskusji podsumowującej udział wzięli: dr Jan Bujak, prof. dr hab. Andrzej Gąsiorowski, dr Adam Bujakowski, dr Ion Constantin i dr Veniamin Ciobanu, który jak zauważono, opuścił tylko jedno sympozjum z 16 dotychczas zorganizowanych. Wszyscy podkreślali wysoki poziom merytoryczny wygłoszonych referatów. Pojawiły się też głosy, że dobrze byłoby, gdyby większa liczba przedstawicieli rumuńskiej nauki zechciała zaprezentować wyniki swoich badań podczas spotkań w Suczawie.

Kolejnym punktem była prezentacja wydawnictw. Jako pierwszą zaprezentowano monografię, która została wydana m.in. jako pokłosie sympozjum z 2013 r., jednakże wzbogaconą o kilka nowych tekstów. Książka ukazała się pod tytułem Polska i Rumunia. Wspólnie - obok blisko. Jej druk został sfinansowany z funduszy polskiego Ministerstwa Spraw Zagranicznych.

Z dumą zaprezentowano także monografię wsi i parafii w Nowym Sołońcu. Autorem tej książki jest ks. Alfons Eugen Zelionca, a jej tytuł brzmi: Nowy Sołoniec. Dzieje wsi i parafii. Książa jest dwujęzyczna: polsko-rumuńska. Poza tym dr hab. Krzysztof Nowak, zaprezentował dwie inne publikacje, które w ostatnim czasie ukazały się w Polsce. Pierwsza z nich, autorstwa Stanislava Cuchareca pt. Odrodzenie w Mołdawii życia religijnego i społecznego Kościoła katolickiego ukazała się nakładem Wydawnictwa Naukowego Uniwersytetu Jana Pawła II w Krakowie. Druga z książek wyszła nakładem Wydawnictwa Uniwersytetu Łódzkiego. Jej autorem jest Andrzej Dubicki. Książka nosi tytuł: System partyjny Królestwa Rumunii. Uwarunkowania i funkcjonowanie. Zaprezentowany został także przez Zofię Kostój album ze zdjęciami wykonanymi przez jej syna Radosława, wielkiego miłośnika Rumunii.

Dni Polskie zostały tradycyjnie zakończone udziałem uczestników w uroczystościach dożynkowych w Nowym Sołońcu. 